LEŚNIAK-MOCZUK Arkadiusz D.,

Doctoral Student

at the University of Białystok

Tel.: +48605144996

E-mail:ad.lesniak@gmail.com

\title{
LEADERSHIP
}

\section{IN THE MANAGEMENT SPHERE}

The aim of this article is to analyze leadership on the example of networked organization of automotive events. The theoretical aspect is revealed in the study of the evolutionary theory of leadership, the path to the goal, the situational decision-making model of Vroom-Yetton-Jago. The distinctive features and effects of network leadership are determined on the basis of the views of P. Drucker and M. Castells. The subject of research is car festivals.

Keywords: volunteering, leadership traits, leadership models, unpaid work.

Лещняк-Мочук А. Лидерство в управленческой сфере. Целью этой статьи является анализ лидерства на примере сетевой организации автомобильных мероприятий. Теоретический аспект раскрывается в исследовании эволюиионной теории лидерства, пути к иели, ситуационной модели принятия решений Врума-Йеттона-Яго. Определены отличттельные черты и эффекты сетевого лидерства на основе взглядов П. Друкера и М. Кастельса. Предметом исследования являются автомобильнье фестивали.

Ключевые слова: волонтёрство, лидерские черты, модели лидерства, неоплачиваемая работа.

Background. The change of the economic model in Poland, following the systematic transformation from a centrally controlled economy into a free-market economy, has resulted in new labour market regulations. Moreover, the form of ownership of the means of production, which is a fundamental economic relation, has changed too. The once dominant public form of ownership, including state ownership, has been largely superseded by private ownership. The introduction of the cost-benefit calculation in the micro- and macro-economic scale has involved, inter alia, new decisions related to workforce. One of the first reforms of the social policies was the rationalization of employment, which caused massive lay-offs. Increasing unemployment, resulting in the necessity to live off social benefits and take advantage of welfare programmes, caused an increase in the eco-

C Leśniak-Moczuk A., 2019

ISSN 1727-9313. ВІСНИК КНТЕУ. 2019. № 5 
nomically-motivated emigration. The ever growing percentage of workingage people who do not have regular employment take advantage of temporary, seasonal and grey-market employment. Young people become active professionally by taking up trainee positions or working as unpaid volunteers for various foundations, associations and other social organizations or movements, so that they may maintain the skills acquired during the education process.

Frequently, work organization does not require regular full-time employment in a specific workplace, with well-defined working time and hours. Work is largely organized in the form of projects, which does not guarantee regular employment, but only temporary, during the duration of the project. Such working conditions are easy to adapt to by young generations who do not have any experience of regular work. Young graduates who do not have or do not seek employment, but, instead, are getting ready for self-employed work, try to acquire experience and various skills, frequently expecting to receive no pay in return for a certain period of time. Hence, unpaid work becomes a springboard for professional life, with postponed remuneration. Through unpaid work, they acquire the resources necessary for working in their own companies or other workplaces.

The ongoing change in the organizational forms in all the spheres of social and economic life of the contemporary networking society, simultaneously subject to the globalization processes, greatly influences the labour market. The previously existing organization structures of companies and institutions, based on permanent hierarchical links between the human and material resources are complemented by networking organization structures. A leader in charge of a networking structure defines the task-oriented and employee-oriented styles in order to optimize the leadership behaviour. An organizer involved in social movements and non-government organizations should have the traits of character of a leader, allowing him/her to influence the volunteers' behaviour through the application of motivating stimuli, without resorting to force. This is because leaders, overcoming bureaucratic barriers, focus on releasing the energy of the volunteers in order to achieve the objectives. For an organization to operate effectively, it is also necessary for the leader to have creative and visionary skills, since leadership means to change the environment where one operates.

The aim of this article is to present a selected example of unpaid work taken up by young people as their contribution to the community. The time devoted by young people to working as volunteers, without any material considerations, such as financial remuneration, brings the intangible results in the form of the acquisition of new skills and the maintenance of the qualifications acquired during the education process, as well as the acquisition of professional experience and the establishment of new interpersonal relations while entering new social milieux. Taking up unpaid work is a great school of leadership for young people predisposed to leadership. 
Materials and methods. The theoretical basis of the article was the scientific works of scientists who investigated the phenomenon of leadership and its impact on the development of society. The theoretical aspect is revealed in the study of the evolutionary theory of leadership, the path to goal, NPW and the situational decision-making model of Vrum-Yetton-Jago. The philosophical methods of cognition (dialectical), general scientific (analysis and synthesis, modelling, abstraction) were used in the study.

In this article, the gist of selected leadership models is explained on the basis of the publications relevant to management, and the leadership qualities are outlined. A leader's tasks are characterized on the example of volunteer work performed, without any pay, by motor sport enthusiasts who organize various motoring events.

Results. The essence of leadership consists in embarking on the activities no one has ever performed yet, since if someone had done something before, an imitator, rather than a leader, would be needed. A leader should influence the people around by informing them, via both traditional and new media, about his/her intentions, should observe the principles of transparency, dissociate oneself from outsiders and support his/her supporters without destroying the opponents. Succeeding in ones activities and making others follow is possible through making creative plans come true, due to doing what one believes in, allowing for the ever-present risk [1, p. 91-93, 95, 97, 102-103, 106-107, 126]. The risk factors inscribed in operating in contemporary social reality are emphasized by Ulrich Beck in his monograph World at Risk [2, p. 25-58].

In order to create a social movement, a leader must articulate a common interest to bind the volunteers and develop the principles of the communication between the leader and the volunteers and between the leaders and the people outside. A leader states the goals, creating previously non-existent undertakings and objects. To implement the goals, he/she invites interested volunteers, getting them together by providing a platform for the exchange of their ideas. The management based on the leader's obligetions consists in managing the resource while being aware of introducing the changes needed by the market. Opponents will take advantage of any mistake preventing one from achieving the goal. That is why most vital is the consistency in making one's dreams come true and the leader's vivid imagination. Success is determined by facilitating change by raising the stakes and breaking the rules. A leader in charge of the social movement he/she initiated gets people together and inspires them in pursuit of the change, together with the volunteers who believe in the need for introducing changes. To achieve the best possible results, a leader will choose the operating tactics on his/her own, having three options available: transforming the interest of the initiated movement into a goal leading to a change; expanding the volunteer group, and optimizing the communication tools, which ensures effectiveness. The appropriate choice of the tactics depends on keeping the 
secrecy of the information about the idea and the products of the movement, and being aware of the lack of a recipe to keep all the co-operating volunteers satisfied. Although the sources of leadership do not spring from the decision-making structures, a leader who commences his/her activities should have a good rapport with those holding positions in local government and seek their support.

The lack of stiff organization structures also pertains to the working time, whereas work is a heartfelt unpaid activity performed to implement the projects one created and is implementing, as well as an activity to the benefit of the local community. The motivations used by leaders towards volunteers do not have to be economic in character. Rather than that, the point is to provide the volunteers with the freedom of actions, so that they perform unpaid work under no compulsion, without a hierarchical order. In a social movement, important is the example set by the leader, who takes the risks to reach ambitious goals, even with a touch of madness, working without pay, without any certainty of success, without any prizes, diplomas of merits or monuments. A leader's attitude must be characterized by the readiness to give, rather than take. He/she should realize that his/her work and dedication are precious and valuable, as not many people can live up to the challenge of being a leader - even if they do have leadership qualities, they may be unwilling to take up unpaid work to implement their ideas. In the case of a failure, a leader must know how to withdraw or soldier on, without giving in to apathy, and know the limits of a compromise [1, p. 18, $21,25-27,31-32,48-50,53,56,62-63,67-68,70,72,76-78,94,104$, 111-120]. Another source of discomfort is the force of unjustified criticism of third parties, jealous and envious of the rising popularity of the leader in the local milieu, in the traditional and internet media, as well as those suspicions of profiteering from his/her activities despite receiving no remuneration. Also, inside the movement led by a leader, antagonisms may arise, posing the threat that the leader who copes well with the problems and the undertaken tasks may still be deprived of leadership.

The effectiveness of a leader is influenced by the following factors: the personality, experience and expectations of the leader; the qualities, expectations and behaviour of the superiors, subordinates and colleagues; the tasks, requirements, culture and principles of the given organization. Leaders' effectiveness depends on the leadership behaviour, seen in how they operate, and the choice of the type of collaboration. A bureaucratic style is stiff and procedure-focused while working. It involves defining the methods of performing the tasks, building the structure of formal communication, providing the information and opinions, as well as supervising. A social style is characterized by the activities that are organic, flexible and take others into account, focused on the preoccupation with the employee satisfaction, maintenance of team integrity by mediating in disputes, creating a friendly atmosphere by motivating and complimenting. As regards the 
boss-oriented leadership, the leader uses the formal prerogatives of his/her authority, whereas in the case of the employee-oriented leadership, employees are given some area of freedom [1, p. 109-111; 3, p. 552-587; 4, p. 382-404].

P. Druker, father of the modern management theory, emphasizes the significance of the knowledge used by leaders in the management and organization process in a post-modern society [5, p. 217]. In leadership, management concepts may be applied, consisting in leading by defining the tasks, delegating responsibilities, allowing for deviation, as well as motivating and supervising based on the results. Also, important is the knowledge and application of the following management principles: defining the goals, dividing and changing the responsibilities, delegating responsibilities, advising, using the collaborators' creative powers, improving one's skills, as well as supervising [6, p. 77-85]. In client-oriented quality management, dedicated to ensuring quality, the key role is played by the leadership based on philosophy [7, p. 132]. Group leaders may face failure due to the inspirations that do not bring the expected results, their own benefiting from excessive privileges, the lack of trust, modesty and honesty, the necessity to overcome prejudices and fallacies, ill-received naturalness, inability to accept criticism and to rectify one's mistakes [8, p. 49-221].

Theoretical concepts are developed due to their significance to leadership effectiveness. Management sciences refer to the following situational theories of leadership: the evolutionary theory, the path-goal theory, the LPC theory and the Vroom-Yetton-Jago decision model. In the evolutionary leadership theory, the leadership style depends on the maturity of the subordinates. In the first stage of the subordinates' 'maturing', the task-oriented style is required. In the second stage, the subordinates do not want to assume the responsibility for the tasks yet. In the third stage, the leader strengthens their aspirations for responsibility by resigning from directive management. In the fourth stage, while the subordinates gain experience and confidence, they lead themselves, not expecting directive relations with their leader.

The path-goal theory is another development of the motivating theory based on the expectations: the probability of achieving the result and the value ascribed to the results. The role of the leader is to provide the subordinates with the prizes they appreciate and to explain what behaviour leads to winning them. The leader may select his/her mode of behaviour towards the subordinates following four models of behaviour: prescriptive, supportive, participatory and achievement-oriented due to defining ambitious goals.

In the least preferred co-worker (LPC) concept, the leadership style changes as a function of the degree of how favourable the situation is, in the sense of the superiority of the leader, the structure of the tasks, the relations between the leader and group members. In consideration of these factors, the least and the most favourable situations require task-oriented leadership, whereas averagely favourable situations require the leadership oriented on interpersonal relations. 
The Vroom-Yetton-Jago decision model describes an autocratic style (the manager makes decisions on his/her own), a consultative style (the manager informs certain team members and makes the decision on his/her own), and a group style (the decision is made by the group and the manager).

One can differentiate between charismatic leadership, transformational leadership and leadership substitutes. The foundation of charismatic leadership are the leader's character traits, which enable him/her to influence others. Charisma shows in self-confidence, belief in ones' convictions and ideals, and the will to influence people. The leader with such qualities must be able to present a vision of the future, formulate expectations, shape behaviour, arouse other people's energy by showing his/her own enthusiasm, trust and patterns of success. Transformational leadership (inspiring, symbolic) conveys the sense of a mission, stimulates the learning processes, inspires new ways of thinking, going beyond the expectations. The tenets of this concept include: expert knowledge, creating a mission, taking risks, encouraging different opinions, simplifying issues and remaining calm [1, p. 109-111; 3, p. 552-587; 4, p. 382-404; 9, p. 36-38].

In a society associated with the 'digital age', the virtual world creates opinion leaders and makes it possible to communicate with millions of stakeholders in real time, regardless of their location [9, p. 9-26]. In a world wide web society, a leader enjoys independence enabling him/her to operate in various social configurations, being a member of numerous networking communities. A leader's task is to simulate the activity of the volunteers interested in co-operating with a given organization and releasing their creative forces necessary for completing the tasks given to them by a social movement [10, p. 127-128, 132-133]. Manuel Castells differentiates between networking power, network power, networked power and network-making power [11, p. 40, 53-58]. From the point of view of the leadership in a networking organizational structure, teams of different sizes are created as the nodes (vortices), from which one of the hierarchical nodes emerges to perform the role of the key node. Instead of a hierarchy of authority, a hierarchy of tasks is established. In network-like organized entities, project management based on the distribution of the tasks, communicative effectiveness, as well as creativity and effectiveness is an important and sociologically uninvestigated area where bonds are created between the nodes (medium and senior management, employees, business partners and subcontractors) [12].

The well-known theories of leadership in a digital society include the theories of authentic leadership, limited leadership and the leadership that goes beyond the borders of the organization. In the authentic leadership model, emphasized are self-consciousness, relative transparency, openness to feedback and ethical behaviour. Authentic leadership is supported by the new social media, due to which leaders may co-operate with their subordinates directly, receiving immediate feedback. This type of leadership is characterized by transparency, honesty and openness. The limited leader- 
ship theory points to the operating conditions of the leaders forced to choose non-optimal solutions due to political, ethical, cultural, institutional, informational, motivational and emotional limitations. In the leadership that goes beyond the borders of the organization, destination borders are outlined, which define the common goal for the interested group members: demographical ones (concerned with sex or age), geographical ones (related to the location), as well as vertical and horizontal ones (inscribed in the organization structure) [9, p. 35-46].

Aspects of Young Volunteers' Unpaid Work on the Example of Motor Sport Enthusiasts.

By applying the technique of participant observation, an analysis and assessment have been made of the leadership activities in the structure of the volunteer group active in the area of motor sports during the organization of drift sport events by the motor sport enthusiasts in Rzeszów, Poland. Motor sport fans, promoting the idea of the construction of a drift track in Rzeszów as unpaid volunteers, have been organizing campaigns and events in support of the development of motor sports. The situational approach to leadership has been analysed at the time of creating the volunteer movement, as well as promoting and holding the periodical Motor Sport Festival event.

To prepare and hold such an event, a massive organizational structure is necessary, so the work of the volunteer group leader begins months before the date of the competition. Leaders performing unpaid volunteer's work, as well as the volunteer group members, take advantage of the many-year-long experience of the professionals organizing large-scale motor sport events of local, nationwide, etc., significance. The organizers' task - whether they are professionals or volunteer enthusiasts - is to provide the finance and plan the budget. The organizers must provide racing tracks, yards, parking areas and public roads that have to be excluded from public use throughout the duration of the event, as well as the spectator stands, heavy platform trailers for racing cars, thousands of tyres, repair shops and restaurants. Before the event, special permits must be obtained from the local authorities, police, security services, as well as sanitary and fire-fighting services. It is vital to ensure parking areas, garages, pit stops, water supply lines, a sewage system, electricity with appropriate circuits, lighting systems, public sound systems, fire extinguishers, armbands, ID badges, protective clothing, firefighting, medical and security services, radio contact on the event premises, as well as to appoint the people responsible for renting out retail stands, advertising stands and ticket-selling points. There is the need to hire referees, commentators, a health and safety manager, traffic wardens, accountants and document-processing professionals, people in charge of the bulletins, portals, profiles and websites in the electronic media, as well as volunteers (to perform numerous tasks during the event). In advance, a widespread advertising campaign should be launched in the traditional and new media to promote the event [13, p. 54-65]. 
Despite the growing popularity of motor sports, the access of spectators to particular disciplines is limited, whereas the awareness and knowledge of the subject is still too limited. Hence, the leader's intention is not only to target as many motor sport fans as possible, but also the sports people interested in participating in the event. Young enthusiast, working as unpaid volunteers led by the leader, integrate with one another due to the variety of competitions, shows and other attractions organized within the framework of the Festival. Consequently, Festival activities motivate the ever growing number of volunteering motor sport enthusiasts to embark on further activities and organize consecutive events of the type, improving them continually.

The leader also takes steps to make the Motor Sport Festival increase the motoring culture by promoting the idea of road safety in the context of barriers to road traffic, such as excessively slow increase in the road surface quality and expansion of the road system, despite the very dynamic growth in the number of cars. One of the easily accessible and cheap - which is of importance to unpaid volunteers - means to take advantage of is the Internet, understood not only as the cyberspace, as virtual acquaintances turn into real-life initiatives which become created and promoted with the use of the new media. Event promotion conducted in the social media, e.g. Facebook, and through the information in the press, radio and television proves that the synergy between the new and the traditional media enables the organizers to achieve such objectives at a relatively low cost. For example, Facebook attracted the people in the automotive industry and motor sport enthusiast who knew exactly what to expect, whereas the organizers were able to learn about their expectations.

Being great means of distributing information to both specific and random addressees, and offering the possibility of on-line interaction (cheap, fast and unlimited geographically), the new media run the risk of allowing an instantaneous response of the recipients, who may express unfounded criticism or resort to large-scale hate with impunity.

If interested in the event, the traditional media publish articles, as well as record and broadcast occasional programmes, free of charge, with an eye to increasing the readership, listenership or viewership of their columns, channels and programmes.

Conclusion. Decision-making leaders should be considered creators, since they convey and record their visions, knowledge, experience and beliefs. They make use of their intellect to shape the material space. This creativity is manifest especially at the final stage of decision making, as that stage is always cleared by 'a leap of intuition', when the possibility of providing rational justification is no longer there. This happens in the case of the occurrences that cannot be explained with a simple sum of individual people's behaviour, where complex relations exist that influence the developments of the situation [14, p. 179-180]. An experienced leader with a skill at creating 
long-term strategies prevents the risks related to the problems with coordinating activities, negative outcomes of the wide access to the network members' potential and resources, which might result in the autonomization of network partners, or even adoption of their goals [15, p. 75]. Although computerization has dramatically increased the possibility of making correct predictions, it is still difficult for leaders to acquire the knowledge ensuring the precision of forecasts [4, p. 39-40]. American scholars propose prognostic analysis methods applied to predicting events beforehand, taking advantage of algorithms based on big data processing based on datification, i.e. transformation of the numerical data from all the fields of human life and activity into digital data [16, p. 84, 107-108, 121-122, 138, 177, 181].

The responsibility for the course of the event organization process lies with the leader, together with the team of the people responsible for the preparing, promoting and holding the event, backed up by the remaining volunteers performing the tasks entrusted to them. The decisions made by the leaders have a decisive influence on the development and operation of a social organization consisting of unpaid volunteers, since the leaders have to set a good example - with their attitudes, creativity, hard work, reliability and altruism - motivating the volunteers to work with commitment to the benefit of the whole project. One must be born as a leader of a volunteer movement, since it is a combination of character traits and competences, such as knowledge, skills and experience, that enables the leader to succeed in the face of numerous challenges, under varied and unpredictable circumstances, while having to motivate the volunteers to perform dedicated, but still unpaid, work.

The co-ordinator is a key to many doors, but he/she might not succeed without the connection with the junior co-ordinators in charge of particular task sub-teams; thus, only continual co-operation and fast flow of information will lead to the success of the whole event.

To sum up, being a leader of a group organizing an event means continual work on overcoming new difficulties and failures, depending on the skill at reacting to and rectifying the ensuing situations fast.

\section{REFERENCES}

1. Godin, S. (2010). Plemiona 2.0. zostań internetowym przywódca (original title: Tribes: We Need You to Lead Us), transl. by Magda Witkowskaю. Gliwice: Wydawnictwo Helion [in Poland].

2. Beck, U. (2002). Spoleczeństwo ryzyka. W drodze ku nowoczesności (original title: Weltrisikogesellschaft. Auf der Suche nach der verlorenen Sicherheit [World at Risk: The Search for Lost Security]), transl. by S. Cieśla. Warszawa: Scholar [in Poland].

3. Griffin, R.W. (2004). Podstawy zarzadzania organizacjami (original title: Management). Warszawa: PWN [in Poland].

4. Stoner, J. A. F., \& Wankel, Ch. (1994). Kierowanie (original title: Management). Warszawa: Państwowe Wydawnictwo Ekonomiczne [in Poland]. 
5. Barbrook, R. (2009). Przyszłości wyobrażone. Od myślacej maszyny do globalnej wioski (original title: Imaginary Futures: From Thinking Machines to the Global Village), transl. by Jan Dzierzgowski. Warszawa: Wydawnictwo literackie MUZA SA [in Poland].

6. Vollmuth, H. (1993). Controlling. Planowanie, kontrola, zarzadzanie (original title: Führungsinstrument Controlling [Controlling - A Management Tool]). Warszawa: Placet [in Poland].

7. Karaszewski, R. (2006). Nowoczesne koncepcje zarządzania jakościa [Modern Quality Management Concpets]. TNOiK, Stowarzyszenie Wyższej Użyteczności "Dom Organizatora". Toruń [in Poland].

8. Pfeffer, J. (2017). Przywództwo mity i prawda. Jak naprawić karierę i uzdrowić sytuacje w miejscu pracy (original title: Leadership BS: Fixing Workplaces and Careers One Truth at a Time). Poznań: Dom Wydawniczy: Rebis [in Poland].

9. Korzyński, P. (2018). Przywództwo w erze cyfrowej. Sposoby pokonywania ograniczeń na platformach społecznościowych [Leadership in the Digital Age. Methods of Overcoming Limitations on Social Platforms]. Warszwa: Wydawnictwo Poltext [in Poland].

10. Partycki, S. (2014). Regionalizm w cyberprzestrzeni. Doświadczenia i wyzwania przyszłości [Regionalism in Cyberspace. Experience and Future Challenges] [in:] Regionalizm polski 25 lat po transformacji jako ważne źródto odrodzenia narodu i państwa, referaty i prezentacje. Bydgoszcz [in Poland].

11. Castells, M. (2013). Wtadza komunikacji (original title: Communication Power), transl. by Jakub Jedliński, Paweł Tomanek. Warszawa: Wydawnictwo Naukowe PWN [in Poland].

12. Benedyk, E. (2004). Antymatrix. Czlowiek w labiryncie sieci [Anti-matrix. Man in a Network Labyrinth], Warszawa: Wydawnictwo W.A.B. [in Poland].

13. Brzosko, S. (1961). Samochody na torach wyścigowych świata [Cars on the World's Racing Tracks]. Warszawa: Wydawnictwo Komunikacji i Łączności [in Poland].

14. Galata, S. (2007). Podstawy zarzadzania nowoczesna organizacja. Ekonomia. Kultura. Bezpieczeństwo. Etyka [Rudiments of Modern Organization Management. Economics. Culture. Safety. Ethics]. Warszawa: Difin [in Poland].

15. Kołodziejczyk-Olczak, I., \& Olczak, A. (2003). ABC zarządzania [ABC of Management]. Łódź: Wyższa Szkoła Humanistyczno-Ekonomiczna [in Poland].

16. Mayer-Schonberger, V., \& Cukier, K. (2014). Big data. Rewolucja, która zmieni nasze myślenie, prace $i$ życie (original title: Big Data: A Revolution that Will Transform How We Live, Work and Think), transl. by Michał Głatki. Warszawa: MT Ltd. Biznes [in Poland].

The article submitted to editor's office on 12.09.2019.

Лещцяк-Мочук А. Лідрство в управлінській сфері.

Постановка проблеми. Існуючі організачійні структури фірм і установ базуються на сталих ієрархічних зв'язках людських та матеріальних ресурсів, що доповнюються структурами мережевої організаџії. Лідер у мережевій структурі визначає стилі, орієнтовані на завдання та працівників з метою оптимізаиї керівництва. Аніматор у суспільних рухах і неурядових організаціях повинен мати особистісні риси керівника, щъо дають змогу йому впливати на поведінку волонтерів, застосовуючи мотиваиійні стимули, не вдаючись до використання сили. 
Долаючи бюрократичні бар'єри з метою досягнення иілі, лідери зосереджуються на використанні енергї волонтерства. Для ефективного функиіонування організаиії лідеру також необхідно володіти творчими навичками, далекоглядністю, оскільки лідерство прагне до змін навколишнього середовища, в якому функціонує.

Метою иієё статті є аналіз лідерства на прикладі мережевої організації автомобільних заходів. Предметом дослідження є автомобільні фестивалі.

Матеріали та методи. Теоретичну базу статті становили наукові праці вчених, які досліджували феномен лідерства та його вплив на розвиток суспільства. Теоретичний аспект розкрито в дослідженні еволючійної теорї лідерства, иляху до мети, NPW та ситуаиійної моделі прийняття рішень Врума- Йеттона-Яго. У ході дослідження використано філософські (діалектичний), загальнонаукові (аналіз та синтез, моделювання, абстрагування) методи пізнання.

Результати дослідження. Виділено характерні риси і ефекти мережевого лідерства на підставі поглядів П. Друкера і М. Кастельс.

Лідерство в групі, яка організовує заходи - ие тривала робота над новими труднощами та невдачами, щуо базується на вмінні швидко реагувати і виправляти різні ситуаиіï.

Висновки. Волонтерська діяльність без матеріальної користі у вигляді грошової виплати приносить свої результати у вигляді набуття нових умінь і вдосконалення кваліфікації у процесі навчання, набуття професійного досвіду, встановлення міжсособистісних відносин, вступу до нового суспільного середовища. Для молодих людей з лідерськими здібностями волонтерська робота є чудовою школою лідерства.

Ключові слова: волонтерство, лідерські риси, моделі лідерства, неоплачувана робота. 